$1-2020$

\title{
Dual Mobility Bearing Articulations Result in Lower Rates of Dislocation After Revision Total Hip Arthroplasty.
}

\author{
Zachary Kozick \\ Thomas Jefferson University, zachary.kozick@jefferson.edu \\ William Li \\ Thomas Jefferson University, william.li2@jefferson.edu \\ Matthew Sherman \\ Thomas Jefferson University, matthew.sherman@jefferson.edu \\ Camilo Restrepo, MD \\ Thomas Jefferson University, camilo.restrepo@jefferson.edu

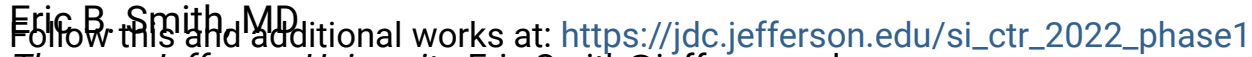 \\ Thomas Jefferson University, Eric.Smith@jefferson.edu \\ Part of the Orthopedics Commons, Surgery Commons, and the Translational Medical Research \\ Commons

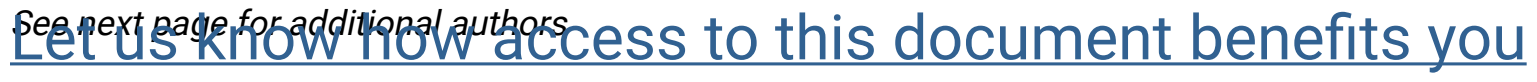

\section{Recommended Citation}

Kozick, Zachary; Li, William; Sherman, Matthew; Restrepo, MD, Camilo; Smith, MD, Eric B.; and Courtney, MD, P. Maxwell, "Dual Mobility Bearing Articulations Result in Lower Rates of Dislocation After Revision Total Hip Arthroplasty." (2020). Phase 1. Paper 47.

https://jdc.jefferson.edu/si_ctr_2022_phase1/47

This Article is brought to you for free and open access by the Jefferson Digital Commons. The Jefferson Digital Commons is a service of Thomas Jefferson University's Center for Teaching and Learning (CTL). The Commons is a showcase for Jefferson books and journals, peer-reviewed scholarly publications, unique historical collections from the University archives, and teaching tools. The Jefferson Digital Commons allows researchers and interested readers anywhere in the world to learn about and keep up to date with Jefferson scholarship. This article has been accepted for inclusion in Phase 1 by an authorized administrator of the Jefferson Digital Commons. For more information, please contact: JeffersonDigitalCommons@jefferson.edu. 


\section{Authors}

Zachary Kozick; William Li; Matthew Sherman; Camilo Restrepo, MD; Eric B. Smith, MD; and P. Maxwell Courtney, MD 
Dual Mobility Bearing Articulations Result in Lower Rates of Dislocation After Revision Total Hip Arthroplasty.

\section{Zachary Kozick, BS; William Li, BS; Matthew Sherman, BS; Camilo Restrepo, MD; Eric B. Smith, MD; P. Maxwell Courtney, MD}

Introduction: The purpose of our study is to directly compare the rates of instability after revision total hip arthroplasty (THA) between a modular dual mobility (DM) and a conventional polyethylene single-bearing surface.

Methods: We retrospectively reviewed a consecutive series of patients who underwent revision THA from 2012 to 2016 at a single institution with a minimum of 2 years of follow-up. Rates of re-revision, dislocation, complications, and short-form (SF-12) scores were compared between the DM and single-bearing groups. To control for confounding variables, a multivariate logistic regression analysis was performed. Results: Of the 267 revision THA patients, 94 patients had a DM bearing articulation (36\%), whereas 173 patients (64\%) had a conventional single-bearing with a mean follow-up of 37.8 months (range 24 to 73 months). The DM group was more likely to undergo revision THA for instability compared with the single-bearing group (8.5\% versus $1.2 \%, P \leq 0.005)$ but had reduced incidence of postoperative dislocations $(2.1 \%$ versus $8.7 \%, P=0.067)$ and no difference in the rates of re-revisions $(9.6 \%$ versus $11.6 \%, P=0.770)$. When controlling for confounding variables, patients who received a 
DM liner had lower rates of dislocation postoperatively than those of single-bearing (odds ratio $0.12, \mathrm{P}=0.019$ ).

Discussion: Even with a selection bias of surgeons using DM for patients at high risk of instability, patients undergoing revision THA with a DM bearing have reduced rates of dislocation at the intermediate-term follow-up. Further study is needed to identify any potential longer-term complications which may result from a modular DM bearing. 